\title{
Strategy implementation: the Critical Link between Strategic planning process and Performance of accredited Universities in Kenya
}

\author{
Dr. Anne Christine Wanjiru Kabui \\ Lecturer, School of Business and Economics \\ South Eastern Kenya University, Kitui Kenya
}

\begin{abstract}
Is the concept of strategic planning falling out of fashion in the $21^{\text {st }}$ century business model or has the how and when of planning become increasingly complex? Strategic planning as a management tool though adopted by many organizations, has not yielded similar outcome. This necessitates further enquiry on causes of discrepancies. The operationalization and institutionalization of strategy during the implementation stage has been conceptualized as a possible mediator in this study. The constant increase in demand for and access to higher education has led to a need for sustainable competitive advantage addressing all university stakeholder. Results indicate that implementation is a significant intervener between planning and performance of universities as partial mediator. The study recommends that all personnel be involved in strategy from formulation to enhance their understanding and participation in implementation. It suggests a longitudinal study to establish patterns at transition from formulation to implementation for further research.
\end{abstract}

Key words; Implementation, Institutionalization, Operationalization, Accredited universities, Planning process

\section{Introduction}

Strategic planning process is commonly used by organizations to respond to and manage change (David \& Kurt, 2019). The process is evolving in its nature of response (Bryson, 2004) depending on the specific organization that applies it. Though strategic planning has been adopted by many organizations over the years, it has not yielded similar outcomes in terms of positively impacting the performance of organizations. Raising the concerns, Could how the strategic plan is implemented through the institutionalization and operationalization of strategy be so unique across organizations that it yields such difference?

Strategy implementation consists of all decisions and activities required to turn strategic plan into reality and refers to the sum total of activities and choices required for the execution of a strategic plan (Wheelen \& Hunger, 2006). It is a systematic process composed of a logical set of inters connected activities (Cater \& Pucko, 2010) through operationalization and institutionalization of the formulated strategy to enable it work. Strategy implementation address the question of who, where, when and how to reach the desired goals and objectives by translating chosen strategy into organizational actions (Brenes et al., 2008). It envisions how organizations are able to develop and consolidate structures, daily operations, systems of control and an organization culture that moves towards set strategy, yielding a competitive advantage and improved performance.

Kenya Vision 2030 places education at the center of its human and economic development strategies with higher education enlisting Kenya as an internationally competitive nation (Ministry of Education, 2012). The constant increase in demand for and access to higher education for training professionals to facilitate this economic growth, in an increasingly competitive global environment, has led to a need for sustainable competitive advantage that addresses all stakeholder needs at the universities. These institutions of higher learning are under the same governing body Commission for University Education (CUE, 2015) and in the same industry which by statutory law are expected to have a strategic plan to guide their operations. This withstanding, their performance in the growth of the enrollment levels, programs on offer and the transition rate continues to differ with the global performance ranking seemingly not following any pattern in line with size, age, financing or ownership (MoEST, 2016). Could the operationalization and institutionalization of their respective strategic plans have a bearing on the effect of these plans on their performance?

\section{Literature review and Hypothesis}


According to Barry (1997) strategic planning process involves methods through which company leadership develops a vision to guide the future of an organization and determine priorities, procedure and operations that are necessary to enable the organization achieve set vision.

Documenting the strategic planning process and availing the document to all stakeholders is a critical component of the planning process (David, 2015). Upon the recasting of strategy during the period of retrenchment, organizations were encouraged to have right planning process, that is flexible; realizing strategic plan is an organic living document, which needs to be flexible to accommodate change (Boyne \& William, 2003) hence it is not just having a strategic plan but going through the strategic planning process that counts.

Strategy implementation is the operationalization and institutionalization of a clearly articulated plan to facilitate for change, (Nobble, 1999; Ouakouak, 2013) which may have a possible effect on the strategic planning process and organizational performance relationship. Most managers have been trained on strategy formulation, know how to develop strategy and spend plenty of resources (both time and money) at the formulation stage but lack knowledge and get fatigue at the implementation stage leading to no change in performance even after resources are spent in formulation (Alexander, 1985; Gluck et al., 1980; Waweru, 2011).

Reviewed literature indicates that the ability of organization to translate documented strategy into action and results is still a challenge for many organizations. David (2013) says that implementation involves managing forces during action stage, requires special motivation and skills while coordinating many individuals. A study by Allio (2005) revealed that without consistent and aligned implementation across functional disciplines; even the best planned strategy becomes ineffective since the planning phase receives significant attention and resources (Noble, 1999) while implementation is neglected. Research indicates that $90 \%$ of well formulated strategies are not implementable due to lack of SMART (Specific, Measurable, Achievable, Realistic and Time bound) approach at formulation. Cater and Pucko (2013) observe that recasting of strategy has called for paying of proper attention to implementation of chosen strategy which has been a major challenge over the years.

Organizational performance is a multidimensional construct and a function of diverse array of factors (Venkatraman \& Ramanujam, 1996; Machuki, 2011) which is a concern for both practioners and researchers. Bryson (2011) says organizational performance is a key concern and central focus of every organization regardless of its industry, whether for profit or not, public or private, large or small. For O'Regan et al (2008) performance measures must be related to activities originating from organization strategic planning efforts that set strategic direction, compare expected and actual outcomes and take necessary corrective actions necessary. The measurement of performance at universities in Kenya is based on growth in programs, student enrollment and graduation rate at the levels of undergraduate, master and doctoral. Another critical measure of university performance is web metric ranking which ranks universities locally and internationally (CUE, 2016). For this study, weighted percentage increase (decrease) in growth variables and the ranking position were used as the operationalization of performance of accredited universities in Kenya.

Institutional theory (Dumaine, 1989; North, 1990) which postulates that the institutional environment can strongly form a basis upon which structures or organization level characteristics are created within the organization informs this study. Institutionalization is both a process and a property variable (Freeman, 1994). It is a process since it is continuous and not a one off activity and property because it is based on what the organization already possess. Institutional theory (North, 1990) at its core is explaining aspects of social structures, how they are formed, shared, adapted and adopted over a period of time and by people operating in the same institution (Amenta, 2005). These structures then become the way that guides formal and informal rules governing social behavior (Johnson, 2002). The environment in which a firm operates will highly influence formation of these structures hence they need to be flexible, allowing change, enhancing efficiency and effectiveness as they are institutionalized. Accordingly when there is a high level of consensus and cooperation within the institutional environment, diffusion of innovation structures is steady and long-lasting.

\subsection{Statement of the problem}

As part of Kenya government directive, all public universities have a strategic plan while the private universities have strategic plan as a means of enhancing efficiency and effectiveness. However even with this, the performance of universities both locally and internationally continues to vary greatly necessitating an empirical study on the execution of these plans. Kaplan and Norton (2005) and Pucko (2008) argue that 95\% of employees in organization are unaware or do not understand the organization strategy hence cannot be very instrumental in implementation. While it is true that poorly formulated strategy may not be implementable, it is important to note that properly formulated strategy may fail if it is not accurately implemented. Accurate implementation is dependent on the ability of an organization to 
operationalize and institutionalize its strategy into actionable activities. Waterman et al., (1988) in their survey explain that $90 \%$ of strategies do not work because implementation failed and this has been researched in regard to the fit between strategy and structure (Hebriniak, 1984 building on the work of Chandler, 1962).

Others study implementation as a variant of leadership processes on a conceptual level (Bourgeois \& Brodwin, 1984) while Chakravarty and Doz (1992); and Floyd (2000) criticize the traditional distinction between formulation and implementation and view them as rather interwoven aspects of strategy process with formulation seamlessly flowing into implementation of the plan.

This study conceptualizes strategy implementation as an intervening variable that has possible mediating effect on the strategic planning on performance of accredited universities in Kenya relationship. The effect of the independent variable on the dependent variable must be through the intervening variable that acts as a mediator between them. According to Chenhall (2017) a strategic plan is expected to be the blueprint for future growth and success of an organization however visioning the future and setting goals will not guarantee results with empirical studies showing that only $9 \%$ of organizations feel that they have the capacity to fully execute their strategy. The study objective is: To establish the influence of strategy implementation on the relationship between strategic planning process and performance and the study hypothesis is;

\section{Hypothesis:}

Strategy Implementation has a significant mediating/intervening effect on the relationship between Strategic planning process and Performance of Accredited Universities in Kenya

\section{Methods}

The study is grounded on positivistic philosophy where theory is tested to establish possible relationship between study variables (Cooper \& Schindler, 2006) with the idea that social world exists externally and can be studied objectively. It uses a cross sectional design where data was collected across universities at one point in time, analyzed, leading to conclusions and recommendations. The population of interest are 70 accredited universities in Kenya as at November, 2016 (CUE, 2016). Primary data was collected on strategic planning process, institutionalization and operationalization of strategy with a semi-structured questionnaire while secondary data was collected on university performance from MoET reports, CUE reports and international web ranking reports. The questionnaire was reliable with values between 0.64 and 0.91 on Cronbach alpha. A response rate of $61.5 \%$ was realized. Normality, multicolinearity, linearity and homoscedasticity as diagnostic tests were done and they confirmed suitability of data for further empirical analysis. A stepwise multiple regression analysis was done to establish the possible mediating effect of strategy implementation on the relationship between strategic planning process and performance of accredited universities in Kenya. Composite values for strategic planning process, strategy implementation and performance were used for the regression analysis. The regression model is stated as; $\mathrm{P}=\mathrm{f}$ (Strategic planning process and Strategy implementation)

$\mathrm{P}=\beta_{0}+\beta_{1} \mathrm{X}_{1}+\beta_{2} \mathrm{X}_{2}+\varepsilon$

Where; $P=$ Performance; $X_{1}=$ Strategic planning process; $X_{2}=$ Strategy Implementation; $\varepsilon=$ Error term and $\beta_{0}, \beta_{1}, \beta_{2}=$ Coefficients

\section{Results and findings}

This study conceptualizes that the relationship between strategic planning process and performance of accredited universities may be mediated by strategy implementation. The effect of strategic planning process leads to a change in strategy implementation which in turn leads to a change in performance through partial or full mediation. Strategy implementation is said to fully mediate this relationship if the effect of strategic planning process on performance fully disappears when controlling for implementation and partial mediation occurs when effect of planning process on performance significantly reduces when controlling for strategy implementation. To test for mediation four critical steps are followed. First test for relationship between independent and dependent variable, second test for relationship between independent and intervening variable; Third test for relationship between intervener and dependent variable and Finally test the combined effect of both independent and intervener on dependent variable. 


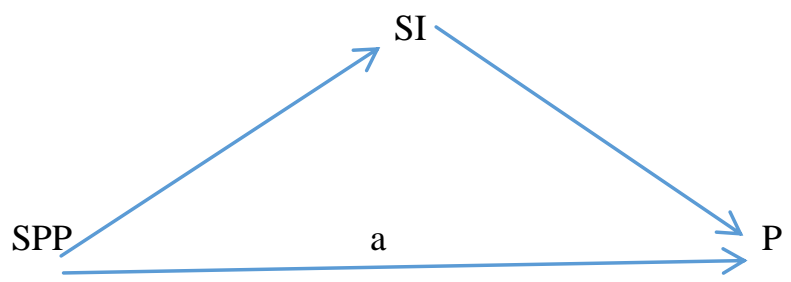

Figure 1: Mediation effect adopted from Baron and Kenny (1986)

The first step tests prediction of the dependent variable from the independent variable which must be significant for there to be a relationship to be mediated. Effect of strategic planning process on performance was tested and results are;

Table 1: Strategic planning process and University Performance

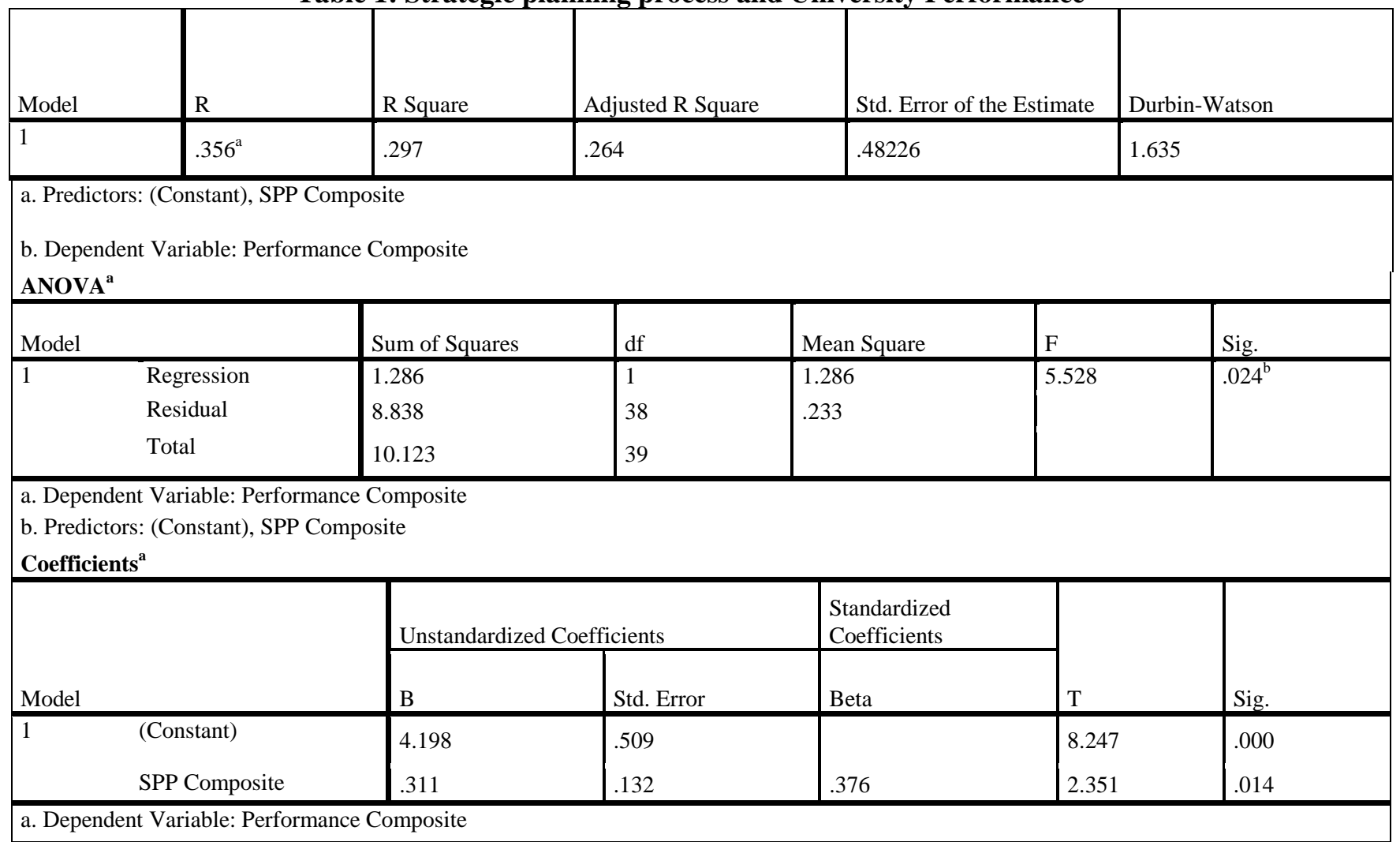

\section{Source: Research Data}

The study results for strategic planning process as a predictor for universities performance is statistically significant as indicated by significant F-value and R-value of 0.356. The relationship between strategic planning process and university performance is however weak since strategic planning process only predicts $29 \%$ of variation in the university performance as indicated by the value of $\mathrm{R}^{2}$. The first condition for the test for mediation has been met.

Second step is predicting the mediating variable from the independent variable which must be significant because if independent variable does not reliably affect the mediator, then the mediator cannot be responsible for the relationship observed between independent variable and dependent variable. 
Table 2: Strategic planning process and Strategy Implementation

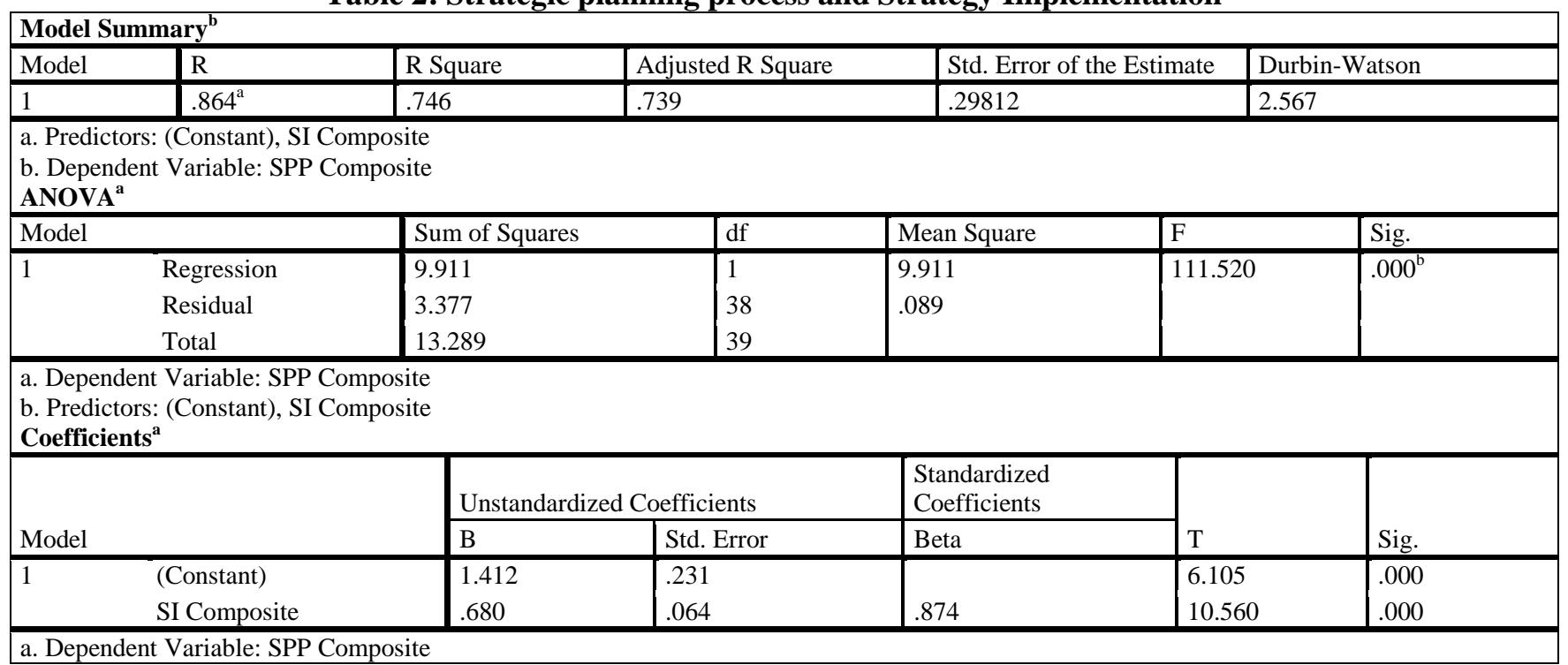

\section{Source: Research Data}

The study established that $74.6 \%$ of variation in strategy implementation is predicted by strategy planning process as indicated by value of $\mathrm{R}^{2}$ and this is a very strong relationship. The regression model of strategic planning process predicting strategy implementation is statistically significant as indicated by the significant $F$ - value and $R$ value of 0.864 . The second condition for the mediation test has been met.

The third step is to predicting the dependent variable from the mediating variable. The coefficient of this effect will assist in calculating the indirect effect of the intervening variable. The predicting effect of implementation on performance results are;

Table 3: Strategy Implementation and University Performance

\begin{tabular}{|c|c|c|c|c|c|c|}
\hline \multicolumn{7}{|c|}{ Model Summary $^{b}$} \\
\hline Model & $\mathrm{R}$ & R Square & Adjusted R Square & \multicolumn{2}{|l|}{ Std. Error of the Estimate } & Durbin-Watson \\
\hline 1 & $.379^{\mathrm{a}}$ & .344 & .321 & .47765 & & 1.620 \\
\hline \multicolumn{7}{|c|}{$\begin{array}{l}\text { a. Predictors: (Constant), SI Composite } \\
\text { b. Dependent Variable: Performance Composite } \\
\text { ANOVA }^{\mathbf{a}}\end{array}$} \\
\hline \multicolumn{2}{|l|}{ Model } & Sum of Squares & df & Mean Square & $\mathrm{F}$ & Sig. \\
\hline 1 & $\begin{array}{l}\text { Regression } \\
\text { Residual } \\
\text { Total }\end{array}$ & \begin{tabular}{|l|}
1.454 \\
8.670 \\
10.123 \\
\end{tabular} & $\begin{array}{l}1 \\
38 \\
39 \\
\end{array}$ & $\begin{array}{l}1.454 \\
.228\end{array}$ & 6.372 & $.016^{\mathrm{b}}$ \\
\hline \multicolumn{7}{|c|}{$\begin{array}{l}\text { a. Dependent Variable: Performance Composite } \\
\text { b. Predictors: (Constant), SI Composite } \\
\text { Coefficients }\end{array}$} \\
\hline \multirow{2}{*}{\multicolumn{2}{|c|}{ Model }} & \multicolumn{2}{|c|}{ Unstandardized Coefficients } & Standardized Coefficients & \multirow[b]{2}{*}{$\mathrm{T}$} & \\
\hline & & B & Std. Error & Beta & & Sig. \\
\hline 1 & $\begin{array}{l}\text { (Constant) } \\
\text { SI Composite }\end{array}$ & \begin{tabular}{|l|}
3.931 \\
.260 \\
\end{tabular} & \begin{tabular}{|l|}
.371 \\
.103 \\
\end{tabular} & .399 & \begin{tabular}{|l|}
10.604 \\
2.524 \\
\end{tabular} & $\begin{array}{l}.000 \\
.018 \\
\end{array}$ \\
\hline
\end{tabular}

Results on table 3 indicate that strategy implementation predicting university performance is statistically significant at $95 \%$ confidence level as indicated by significant $\mathrm{F}$-value and $\mathrm{R}$ of 0.379 . The direct effect of the possible mediator strategy implementation on performance is positive and statistically significant with $34 \%$ of variation in performance explained by implementation hence the third condition for mediation is satisfied.

The final step is to simultaneously predict value of performance from both independent variable strategic planning process and intervening variable strategy implementation using stepwise multiple regression analysis and observe change in the predictive power of the regression models 
Table 4: Strategic planning process, Strategy Implementation and University Performance



Source: Research Data (2017)

Both regression model one and model two are significant as indicated by statistically significant F-values at $95 \%$ confidence level. Model 1 that test for the direct prediction indicates that $29.7 \%$ of variation in university performance is explained by strategic planning process while model 2 indicates that introducing strategy implementation into the model raises the explained variation to $44.7 \%$. The regression coefficient from model 1 to model 2 is substantially reduced at this final stage but it remains significant indicating partial mediation where part of the effect of strategic planning process on performance is partially mediated by strategy implementation and remaining part are either a direct effect or it is mediated by other variables that are not included in this model.

The size of the indirect effect of the mediator is calculated as the product of the direct effect of the independent variable on mediating variable and the direct effect of the mediator on the dependent variable (deLuque et al., 2008; Desai, 2010). In this study, direct effect of strategic planning process on strategy implementation multiplied by direct effect of strategy implementation on performance of universities gives the size of indirect mediation effect;

$\mathrm{SPP} / \mathrm{SI}=\mathrm{R}^{2}$ of.746; $\mathrm{SI} / \mathrm{P}=\mathrm{R}^{2}$ of $.344 \mathrm{R}^{2}$ hence $(.746 * .344=.256624 * 100)$.

The study results indicate that $25.66 \%$ variation in university performance is predicted by strategic planning process through strategy implementation as a partial mediator

\section{Discussion}

Strategy implementation has a statistically significant mediating effect on the relationship between strategic planning process and performance of accredited universities. As the stipulations of the strategic plan are put into actionable tasks, given timelines, assigned to specific individuals and clear performance indicators attributed, then the impact of the strategic planning process on performance is enhanced. Using the path analysis by Baron and Kenny (1986), strategy implementation is a significant mediator between strategic planning process and performance of universities where strategic planning process affects performance through strategy implementation and the effect is doubled when the mediator is introduced. The intervener effect is significant at $95 \%$ confidence level. The mediation effect is partial (Baron \& Kenny, 1986) since the predictive power of strategic planning process on performance substantially rises but does not completely disappear with the introduction of strategy implementation as a mediator.

According to Daft (2000), organization performance is the ability of an organization to attain its goals using human resource and financial resources, in the most efficient and effective manner. The strategic planning process yields a documented outline of what the organization envisions to achieve. 
The strategy implementation translates this into actionable activities with time lines, individuals responsible and resources required. Waweru (2011) state that implementation is the procedures of turning strategic plans into realistic action to achieve specific objectives and goals.

\section{Conclusion}

According to Wheelmen and Hunger (2007), strategy implementation stage provides answers to the three critical questions of who are the people to carry out the strategic plans, what must be done and how are they going to do it. This in essence determines who at the university will be charged with the responsibility of a particular task, what timelines are allocated to them and what outcome it should yield, further it indicates how plan become part of structure, systems and shared values at the university. Noble $(1999,2008)$ defines implementation as the communication, interpretation, adoption and enactment of strategic plans. Strategic plans are put into action through the development of programs, budgets and procedures hence planning and implementation are inseparable.

At a point when university members feel that their input counts as a result of inclusiveness in the planning process, their efforts in implementation for success will be felt. According to David (2013), strategy implementation involves managing forces during action which requires special motivation skills and coordination of many individuals. Muturi and Maroa (2015) state that the implementation stage seeks to create a fit between organization formulated goals and its ongoing activities and this fit is important in enhancing that an organization is able to achieve its set goals within the stipulated time. Lehner (2004) argue that strategy implementation and strategic planning are inseparable since one leads to the other seamlessly.

This study finding affirms the postulations of the institutional theory as an anchoring theory that modern organization depends on their environment which can strongly influence the development of formal organization structures. Galbraith (2002) and Kim (2010) concurs that factors such as structure, strategy, culture, policies, practices and technology are important contributors to organizational performance. These structures and the culture form the basis upon which strategy implementation lies as it operationalizes and institutionalizes strategy.

\section{Implication and suggestion for further research}

It is important that the MoEST and the CUE in their policy formulation efforts continually encourage universities to have strategic planning process that is inclusive of most if not all stakeholders.

This should especially include the teaching and non-teaching members of staff for when they are involved in the planning process, they easily join in and own the implementation gearing the achievement through institutionalization and operationalization. There is need to support universities especially in terms of policy on completion or graduation rate since as evidenced from the findings, there is a large discrepancy between the enrollment level and the completion rate. The ranking of Kenya universities at a global level is mainly average tending toward below average; this calls for policy on how to improve the quality of research and the dissemination of findings with an aim of improving the web ranking performance. To be globally competitive and address the challenges of the $21^{\text {st }}$ century, universities need to align their programs to the market dictates, enhance quality and relevance and aim at facilitating realization of the social pillar of the Kenya vision 2030 (Kenya Vision 2030).

An extension of research into other industries with different performance measures to enhance comparison of findings will facilitate the possibility of generalizing the findings across industry. Current study focused on the education sector which has unique and non-financial performance measures. This would extend knowledge frontiers and enable comparison of results and finding of critical variation. Further research can be a longitudinal study to establish patterns at transition from formulation to implementation in the universities over a duration of time to observe possible effects when universities have gone through several cycles of strategic plans.

\section{References}

Allexander, J.M., \& Schwanenflugel, P.J. (1994). Strategy regulation: The role of intelligence, metacognitive attributions and knowledge base. Developmental Psychology, 30 (5), 709.

Allio, M.K. (2005). A short practical guide to implementing strategy. Journal of business strategy, 26 (4), 12 -21.

Allio, R. J. (2005). Leadership development: teaching versus learning. Management Decision, 43 (7/8), 1071 - 1077.

Baron R., \& Kenny D., (1986). Moderator - Mediator variables distinction in social psychological research: Conceptual, strategic and statistical considerations. Journal of personality and social psychology, 51 (6), $1173-1182$ 
Barry, B., Darden, W., \& Griffin, M. (1994). Work and or fun: Measuring hedonic and utilitarian shopping value. Journal of consumer research, 20 (4), $644-656$.

Boyne, G. (2001). Planning, Performance and Public Services. Journal of Public Administration, 79(1), 73-88

Boyne, G., \& Gould-Williams, J. (2003). Planning and Performance in Public Organizations an empirical analysis. Public Management Review, 5 (1), 115 - 132

Brenes, E.R., Mena, M., \& Mollina, G.E. (2008). Key success factors for strategy implementation in Latin America. Journal of Business Research, 61 (6), 590 - 598

Bryson, J (2004). Strategic planning for public and nonprofit organizations ( $3^{\text {rd }}$ ed). San Francisco, CA: Jossey-Bass

Bryson, J (2011). Strategic planning for public and nonprofit organizations: A guide to strengthening and sustaining organizational achievement, $4^{\text {th }}$ Ed. John Wiley and Sons Ltd.

Cater, T., \& Pucko, D. (2010). Factors of effective strategy implementation: Empirical evidence from Solvenian business practice. Journal for East European Management Studies, 207-236

Chakravarty, B. \& Doz, Y. (2003). Knowledge management and competitive advantage. Handbook of Organizational Learning and Knowledge Management. Australia: Blackwell Publishing

Chavunduka D., Chimunhu P., \&Sifile O., (2015). Strategic Planning intensity and organizational performance: A case of Zimbambwe mining development corporation. European Journal of Business and Management, 7 (5), 40- 64

Chen, Y. (2010). The continuing debate on firm performance; A multilevel approach to the IT sector of Taiwan and South Korea. Journal of Business Research, 63, 471-478

Chenhall, R., (2005). Integrative strategic performance measurement systems, strategic alignment of manufacturing, learning and strategic outcomes. An exploratory study. Accounting, organizations and society, 30 (5); $395-$ 422

Commission for University Education (2014). Comparative Analysis of Higher Education Systems. Nairobi, Kenya

Commission for University Education- Kenya (2014). Universities Authorized to operate in Kenya. cue.or.ke

Commission for University Education-Kenya (2013). The commission for university education strategic plan 2014 2018. Nairobi, Kenya; Government Press

Cooper, D. \& Schindler, P. (2006).Marketing Research. New York: McGraw-Hill

Cooper, R., \& Schindler, S., (2003). Business Research Methods $\left(8^{\text {th }}\right.$ Ed). Boston Irwin McGraw - Hills

Daft, R. I. (2007). Understanding the Theory and Design of Organizations. Thompson South Western: Western Publishing Company.

Daft, R., (2000). Organizational theory and design $\left(7^{\text {th }}\right.$ Ed). South western college publishing. Thompson learning U.S.A

David F., (1999). Strategic Management Concepts and Cases. $7^{\text {th }}$ Ed. New Jersey: Prentice Hall

David F., (2015). Strategic Management Concepts and Cases. ${ }^{\text {th }}$ Ed. New Jersey: Prentice Hall

Dumaine, B. (1989). How managers can succeed through speed. Fortune, 199 (4),

Floyd, S.W., \& Lane, P.J. (2000). Strategizing throughout the organization: Managing role conflict in strategic renewal. Academy of management review, 25 (1), 154 - 177

Freeman, R.E., Wicks, A.C \& Parmar, B. (2004). Stakeholder theory and the corporate objectives revisited. Organization Science, 15(3), 364-369.

Hendricks K. B., (2001). Firm characteristics, Total quality management and Financial performance. Journal of Operations Management, 5

Hendricks, K., \&Singhal V., (2001). Firm characteristics, total quality management and financial performance. Journal of Operations Management, 19; 269-285

Johnson G., \& Scholes K., (1984). Exploring corporate strategy. Prentice Hall International

Kaplan, R. \& Norton D. (2001). Transforming Balanced Scorecard from Performance Measurement to Strategic Management. Part 1, Accounting Horizons; 87-104

Lehner, J. (2004). Strategy implementation tactics as response to organizational, strategic and environmental imperatives. Management Review, 15(4), 460-480.

Machuki, V. (2011). Macro environment, strategy co-alignment, organizational level and performance of publicly quoted companies in Kenya.(Unpublished PhD Thesis). School of Business, University of Nairobi

Ministry of Education (2012). Task force on the alignment of the education sector to the constitution of Kenya, 2010. Towards a globally competitive quality education for sustainable development. Report of the task force, February, 2012.

Ministry of Education Science and Technology (2014). Teaching and Research in Contemporary Higher Education

Ministry of Higher Education, Science and Technology (2013). Strategic plan 2013-2017 
Muturi W. \& Maroa J. (2015). Influence of strategic management practices on the performance of floriculture firms in Kenya, a survey of Kiambu county Kenya. International Journal of Economics, Commerce and Management, 4(2), 51-63

Nobble, C. H., (2008). The roots of Strategy Implementation. Measuring Business Excellence, 12 (3).

Noble, C. H. (1999). The Eclectic Roots of Strategy Implementation Research. Journal of Business Research, 45, 119-134

North D. (1990). Institutions, Institutional change and Economic performance. Cambridge University press

North, D.C. (1990). A transaction cost theory of politics. Journal of Theoretical Politics, 2(4), 355-367

North, D.C. (1993). Institutions and credible commitment: The New institutional Economics recent progress; Expanding frontiers. Journal of Institutional and Theoretical Economics, 149(1), 11-23

O’Regan, N., Sim, M., \&Galler, D., (2008). Leaders, loungers, laggards; The strategic planning - environment performance relationship revisited in manufacturing SMEs. Journal of manufacturing Technology management, 19 (1), 6-21

Pucko, D., (2008). A holistic strategy Implementation model based on the experiences of Slovenian companies. Economic \& Business Review

Venkatraman N. \& Ramanujam V. (1996). Measurement of business performance in strategy research: A comparison of approaches. Academy of Management Review, 1 (4), 801-814

Vision, K. (2012). 2030. (2011). Printed \& Published by the Director, Indian Institute of Pulses Research (ICAR), Kanpur-208024

Waweru, M. (2011). Comparative analysis of competitive strategy implementation. Journal of Management and Strategy, 2 (3), 49-61

Wheelen T. \& Hunger D., (2000). Strategic management and business policy entering $21^{\text {st }}$ century Global society $\left(7^{\text {th }}\right.$ Ed). London Prentice Halls 